RPP-6564

Revision 0

\title{
Business System Planning Project, Preliminary System Design
}

S. Evosevich Lockheed Martin Services, Inc.

Date Published

October $\mathbf{2 0 0 0}$

Prepared for the U.S. Department of Energy

Assistant Secretary for Environmental Management

$\frac{\text { Chin Stillongfhand }}{\text { Rolease Approval }} \frac{10 / 30 / 00}{\text { Dato }}$

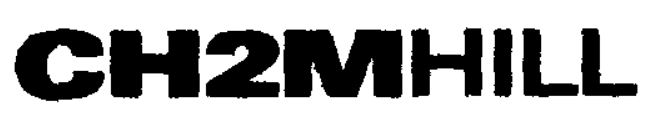

Hanford Group, Inc.

Richland, Washington

Contractor for the U.S. Department of Energy

Office of River Protection under Contrect DE-ACO6-89RL14047

Approved for Public Release; Further Dissemination Unlimited 
LEGAL DIBCLAMER

This report wes prepared as an account of work sponeored by an egency of the United States Government. Neither the

United States Government nor eny egency thereof, nor eny of their omployess, nor any of their contractors, subcontrectors or their employess, makes any warranty, expreses or implied, or sssumes any legel liability or responsibility for the accuracy, completeness, or any third party's use or the results of such use of any information, apparatus, product, or process disclosed, or represents that its use would not infringe privately owned rights. Reference horoin to any specific commercial product, process, or service by trade name, trademark, manufacturer, or otherwise, does not necessarily constitute or imply its endorsement,

recommendation, of fevoring by the United Stetes

Government or any spency thereof or its contractore or subcontractors. The viows and opinions of authore expressed herein do not necesserily state or reflect those of the United States Government or any agency thereof.

This report has been reproduced from the best aveilable copy. Aveilable in peper copy

Printed in the United Stetes of Americe 


\section{INFORMATION CLEARANCE FORM}

\begin{tabular}{|c|c|c|}
\hline \multicolumn{2}{|c|}{ A. Information Category } & B. Document Number RPP -6564 \\
\hline$\square$ Abstract & $\square$ Journal Article & C. Title \\
\hline$\square$ Summary & $\square$ internet & Business Systems Planning Pooject, Preliminary System Design \\
\hline$\square$ Visual Aid & $\square$ Software & \\
\hline$\square$ Full Paper & $\bigotimes$ Report & \\
\hline$\square$ Other & & D. Internet Address \\
\hline
\end{tabular}

\section{E. Required Information}

1. Is document potentially Classified? $\square$ No $\square$ Yes (MANDATORY

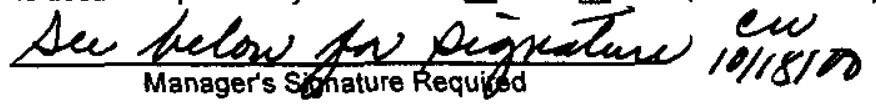

If Yes $\square$ No $\square$ Yes Classified ADC Signature Required

2. Internal Review Required? If Yes, Document Signatures Below

No $\bigotimes$ Yes

Counsel

Program

3. References in the Information are Applied Technology $\bigotimes_{\text {No }} \square$ Yes Export Controlled Information $\bigotimes_{\text {No }} \square$ Yes
4. Does Information Contain the Following: (MANDATORY)

a. New or Novel (Patentable) Subject Matter? $\bigotimes_{\text {No }} \square$ Yes If "Yes", Disclosure No.:

b. Information Received in Confidence, Such as Proprietary and/or Inventions? $\bigotimes$ No $\square$ Yes If "Yes", Affix Appropriate Legends/Notices.

c. Copyrights? $\square$ No $\square$ Yes If "Yes", Attach Permission.

d. Trademarks? $\square$ No $\square$ Yes If "Yes", Identify in Document.

5. Is Information requiring submission to OSTI? $\quad$ No $\square$ Yes

If Yes $U C$ - _

6. Release Level? $\bigotimes$ Public $\square$ Limited

7. Charge Code 112656 AJ 60

F. Complete for a Journal Article

1. Title of Journal

G. Complete for a Presentation

1. Title for Conference or Meeting

2. Group Sponsoring

3. Date of Conference

5. Will Information be Published in Proceedings? $\square$ No $\square$ Yes

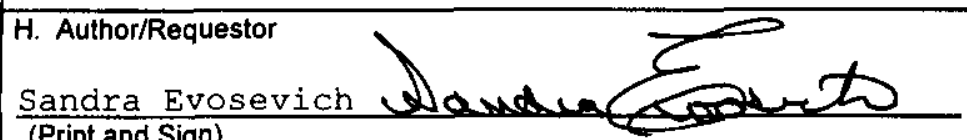
(Print and Sign)

\begin{tabular}{lll}
\hline I. Reviewers & Yes & Print \\
General Counsel & $\bigotimes$ & Stan Bensussen \\
Office of External Affairs & $\square$ & \\
DOE-RL & $\square$ & Kevin Ensign \\
Other & $\square$ & \\
Other & $\square$ &
\end{tabular}

4. City/State

6. Will Material be Handed Out? $\square$ No $\square$ Yes

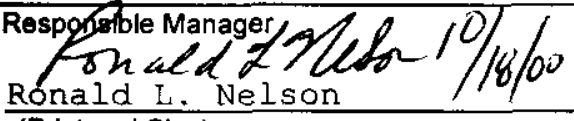

Ronald L. Nelson

(Print and Sign)

Signature

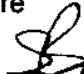

Public Y/N (If N, complete J)

$$
\begin{aligned}
& Q / N \\
& Y / N \\
& Y / N \\
& Y / N \\
& Y / N
\end{aligned}
$$

J. If Information Includes Sensitive Information and is not to be released to the Public indicate category below.

$\square$ Applied Technology $\square$ Protected CRADA

$\square$ Personal/Private $\square$ Export Controlled

$\square$ Proprietary $\square$ Procurement-Sensitive

$\square$ Business-Sensitive $\square$ Patentable

$\square$ Predecisional $\square$ Other (Specify)

$\square$ UCNI

K. If Additional Comments, Please Attach Separate Sheet

peze 182

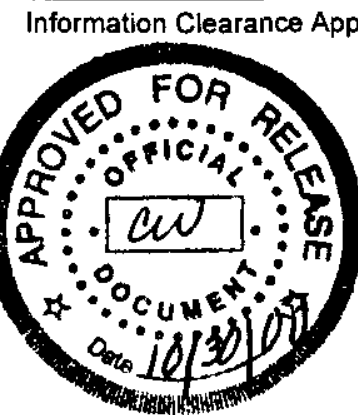




\section{INFORMATION CLEARANCE FORM}

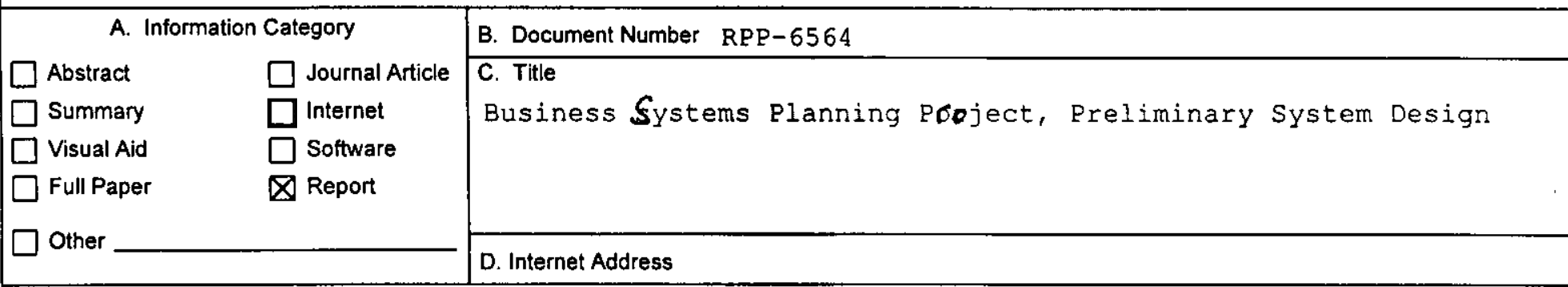

E. Required Information

1. Is document potentially Classified? $\square$ No $\square$ Yes (MANDATORY)

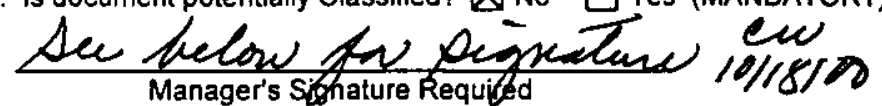

If Yes

$\square$ No $\square$ Yes Classified ADC Signature Required

2. Internal Review Required? If Yes, Document Signatures Below

No $\bigotimes$ Yes

Counsel

Program

3. References in the Information are Applied Technology $\bigotimes$ No $\square$ Yes Export Controlled Information $\bigotimes_{\text {No }} \square$ Yes
4. Does Information Contain the Following: (MANDATORY)

a. New or Novel (Patentable) Subject Matter? $\square$ No $\square$ Yes If "Yes", Disclosure No.:

b. Information Received in Confidence, Such as Proprietary and/or Inventions? $\bigotimes$ No $\square$ Yes If "Yes". Affix Appropriate Legends/Notices.

c. Copyrights? $\square$ No $\square$ Yes If "Yes", Attach Permission.

d. Trademarks? $\bigotimes$ No $\square$ Yes If "Yes", Identify in Document.

5. Is Information requiring submission to OSTI? $\quad$ No $\square$ Yes

If Yes $U C-$

6. Release Level? $\bigotimes$ Public $\square$ Limited

7. Charge Code 112656 AJ 60

\section{F. Complete for a Journal Article}

1. Title of Journal

G. Complete for a Presentation

1. Title for Conference or Meeting

2. Group Sponsoring

3. Date of Conference

5. Will Information be Published in Proceedings? $\square$ No $\square$ Yes

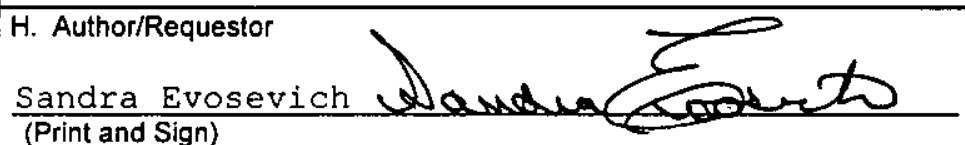
(Print and Sign)

I. Reviewers Yes Print

区

Stan Bensussen

General Counsel

Office of External Affairs

DOE-RT ORP

$\square$

Kevin Ensign

4. City/State

6. Will Material be Handed Out? $\square$ No $\square$ Yes

Other

$\square$

Other

प.

J. If Information Includes Sensitive Information and is not to be released to the Public indicate category below.
$\square$ Applied Technology
$\square$ Personal/Private
$\square$ Protected CRADA
$\square$ Proprietary
$\square$ Export Controlled
$\square$ Business-Sensitive
$\square$ Procurement-Sensitive
$\square$ Predecisional
$\square$ Patentable
$\square$ UCNI
$\square$ Other (Specify)

K. If Additional Comments, Please Attach Separate Sheet
Public $Y / N$ (If $N$, complete $J)$

Signature
$\mathrm{Y} / \mathrm{N}$
$\mathrm{Y} / \mathrm{N}$
$Y / N$
$\mathrm{Y} / \mathrm{N}$
$\mathrm{Y} / \mathrm{N}$

Information Clearance Approval 


\section{Business Systems Planning Project}

\section{Preliminary System Design}

Prepared for:

CH2M HILL Hanford Group, Inc.

R. L. Nelson

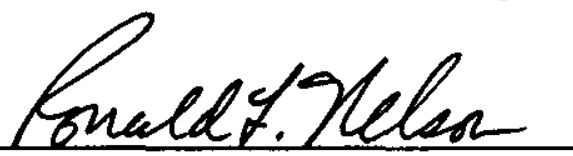

Date: $9 / 27 / 00$

Manager, Information Resource Management / Chief Information Officer, CH2M HuLL Hanford Group, Inc.

P. B. Isaacs<smiles>CC1=CC=C1C</smiles><smiles>C1CCC1</smiles>

Date: $9 / 22 / 00$

Project Lead, Lockheed Martin Services, Inc.

Prepared by

Lockheed Martin Services, Inc. 


\section{Table of Contents}

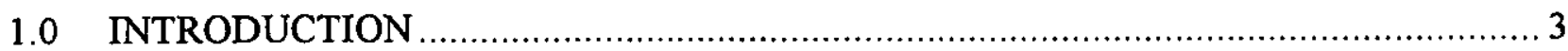

1.1 PURPOSE

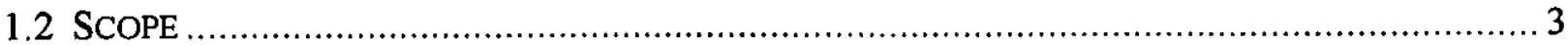

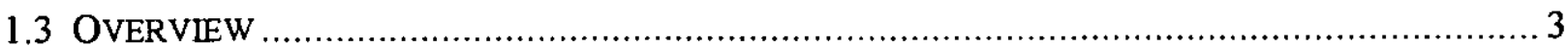

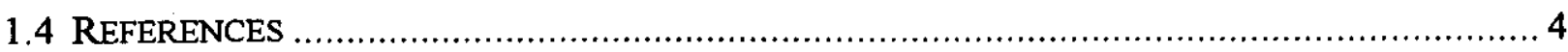

1.5 DEFINTTIONS

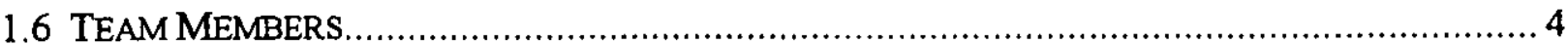

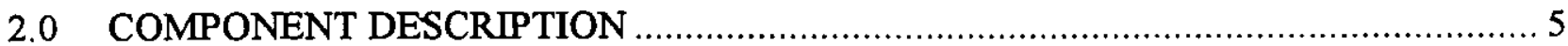

2.1 MICROFUSION MILLENNIUM AND WINSIGHT PROJECT CONTROLS .................................. 5

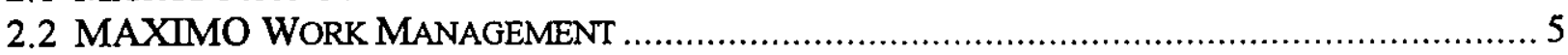

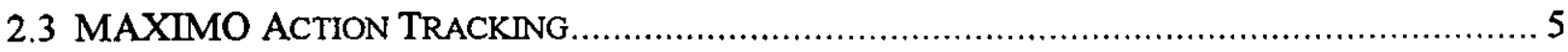

2.4 PEOPLESOFT PURCHASING/ACCOUNTS PAYABLE AND MAXIMO INVENTORY .................. 5

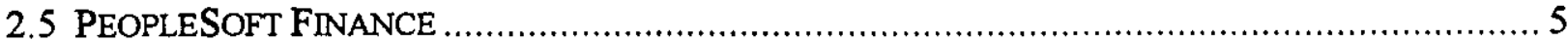

2.6 PEOPLESOFT HUMAN RESOURCES INFORMATION SYSTEM …........................................ 5

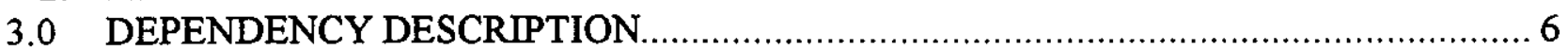

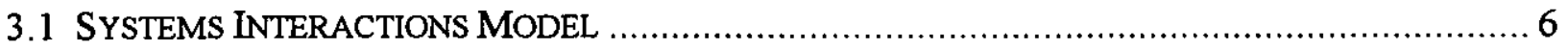

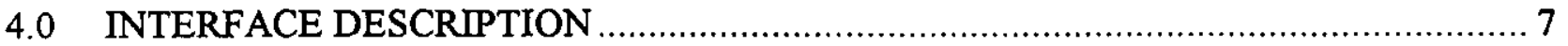

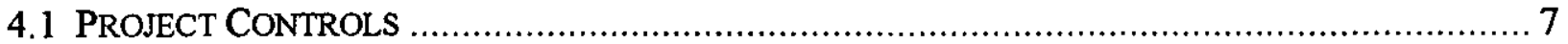

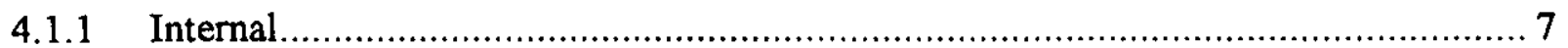

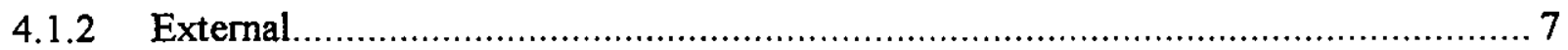

4.2 WORK MANAGEMENT, INVENTORY AND ACTION TRACKING ……................................. 7

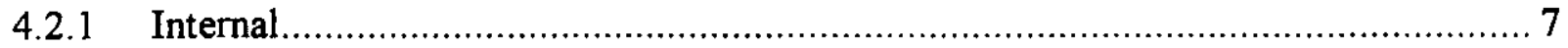

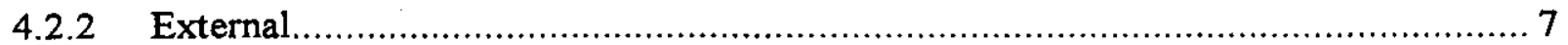

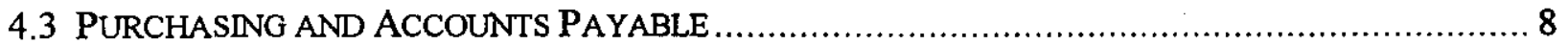

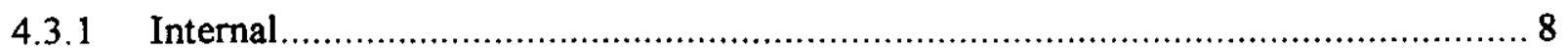

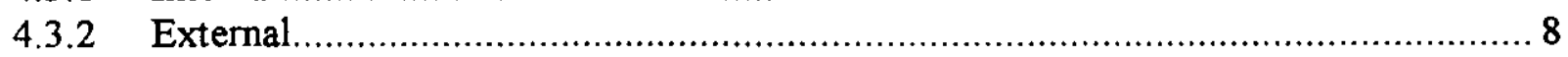




\subsection{INTRODUCTION}

CH2M HILL Hanford Group, Inc. (CHG) is currently performing many core business functions including, but not limited to, work control, planning, scheduling, cost estimating, procurement, training, and human resources. Other core business functions are managed by or dependent on Project Hanford Management Contractors including, but not limited to, payroll, benefits and pension administration, inventory control, accounts payable, and records management. In addition, CHG has business relationships with its parent company CH2M HILL, U.S. Department of Energy, Office of River Protection and other River Protection Project contractors, government agencies, and vendors.

\subsection{PURPOSE}

The Business Systems Planning (BSP) Project, under the sponsorship of the CH2M HILL Hanford Group, Inc. Chief Information Officer (CIO), have recommended information system solutions that will support CHG business areas. The Preliminary System Design was developed using the recommendations from the Alternatives Analysis, RPP - 6499, Rev 0 and will become the design base for any follow-on implementation projects.

\subsection{SCOPE}

The Preliminary System Design will present a high-level system design, providing a high-level overview of the Commercial-Off-The-Shelf (COTS) modules and identify internal and external relationships. This document will not define data structures, user interface components (screens, reports, menus, etc.), business rules or processes. These in-depth activities will be accomplished at implementation planning time.

\subsection{OVERVIEW}

The following sections will provide a high-level decomposition, dependencies, and interface descriptions for the software products.

The following briefly describes the content of each section:

- Section 2.0, Component Description This section provides a high-level understanding of the Project Controls, Work Management, Action Tracking, Purchasing, Inventory and Accounts Payable COTS products and the existing shared systems.

- Section 3.0, Dependency Description This section defines the interaction among the software modules. The dependency description is expressed through a model.

- Section 4.0, Interface Description This section provides a high-level description of the internal and external interfaces. 


\subsection{REFERENCES}

- Business Systems Planning Project System Requirements Specification, RPP-6297, Rev.0.

- Business Systems Planning Project Alternatives Analysis, RPP-6499, Rev.0.

- Lockheed Martin Services, Inc. Organization Standard Software Practices, Version 3.2.

- Institute of Electrical and Electronics Engineers Standard 8340-1984.

\subsection{DEFINITIONS}

\begin{tabular}{|l|l|}
\hline B & Beriniti \\
\hline BMS & Business Management System \\
\hline BSP & Business Systems Planning \\
\hline CHG & CH2M HILL Hanford Group, Inc. \\
\hline CIO & Chief Information Officer \\
\hline COTS & Commercial-Off-The-Shelf \\
\hline FH & Fluor Hanford, Inc. \\
\hline HRIS & Human Resources Information System \\
\hline INFOT & InfoTech West, Inc. \\
\hline LMSI & Lockheed Martin Services, Inc. \\
\hline NISI & Northwest Instrument Systems, Inc. \\
\hline P3 & Primavera Project Planner \\
\hline TIS & Time Information System \\
\hline
\end{tabular}

\subsection{TEAM MEMBERS}

\section{Team Member}

Ronald L. Nelson

P. Brian Isaacs

Joyce A Caldwell

Kelly A. Crace

Sandra Evosevich

Jimmy K. Hamilton

Melody J. Kendall

Eldon C. Ladd

Diana L. Marquez
Business Area Information Resource Management / CIO

Project Lead

Material Management

Work Management

Material Management

Work Management

Action Tracking

Project Controls

Project Controls
Company

CHG

LMSI

LMSI

LMSI

LMSI

CHG

LMSI

NISI

INFOT 


\subsection{COMPONENT DESCRIPTION}

This section provides a high-level understanding of the Project Controls, Work Management, Action Tracking, Purchasing, Inventory and Accounts Payable COTS products. This section also provides a high-level understanding of the existing shared systems.

\subsection{Microfusion Millennium AND winsight Project Controls}

The commercial products of Integrated Management Concept's MicroFusion Millennium and the C/S Solutions' wInsight provide a repository for the resource pricing, cost estimating, project performance and earned value analysis data. The wInsight is a reporting product that compliments Millennium with a comprehensive set of performance reports providing drill down capabilities.

\subsection{MAXIMO WORK MANAGEMENT}

MAXIMO, from Project Software and Development, Inc., is an integrated suite of modules that supports the equipment maintenance function. In addition to equipment maintenance, MAXIMO includes functionality for inventory, lock out/tag out, scheduling, as well as integration to external systems such as Primavera Project Planner (P3). MAXIMO is designed to allow local tailoring to adjust for customer specific needs. MAXIMO has workflow capabilities that can be designed to support work management processes.

\subsection{MAXIMO ACTION TRACKING}

MAXIMO Action Tracking.integrates with the MAXIMO Work Management suite of modules and can be tailored to support other business areas and functions.

\subsection{PeopleSoft Purchasing/Accounts Payable and MaXimo Inventory}

PeopleSoft Material Management consists of Purchasing and Accounts Payable. The Purchasing module includes the Contracts function. The MAXIMO Inventory module integrates with MAXIMO Work Management and will interface with PeopleSoft Purchasing and Accounts Payable.

\subsection{PeopleSoft Finance}

PeopleSoft Finance is a component of the existing Business Management System (BMS) that $\mathrm{CHG}$ shares in the use of. Finance consists of General Ledger and Project Costing modules. In the Fall 2000, CHG worked with Fluor Hanford, Inc. (FH) to implement a multiple company capability, allowing CHG to manage and maintain a separate set of financial books.

\subsection{PEOPLESOFT HUMAN RESOURCES INFORMATION SYSTEM}

PeopleSoft Human Resources Information System (HRIS) is a component of the existing Business Management System (BMS) that CHG shares in the use of. HRIS consists of Human Resources, Training and Payroll PeopleSoft modules and the Time Information System (TIS), a custom application. 


\subsection{DEPENDENCY DESCRIPTION}

This section shows the interactions among the Project Controls, Work Management, Action Tracking, Purchasing, Inventory and Accounts Payable modules. This section also shows the high-level interaction with external applications.

\subsection{SYSTEMS INTERACTIONS MODEL}

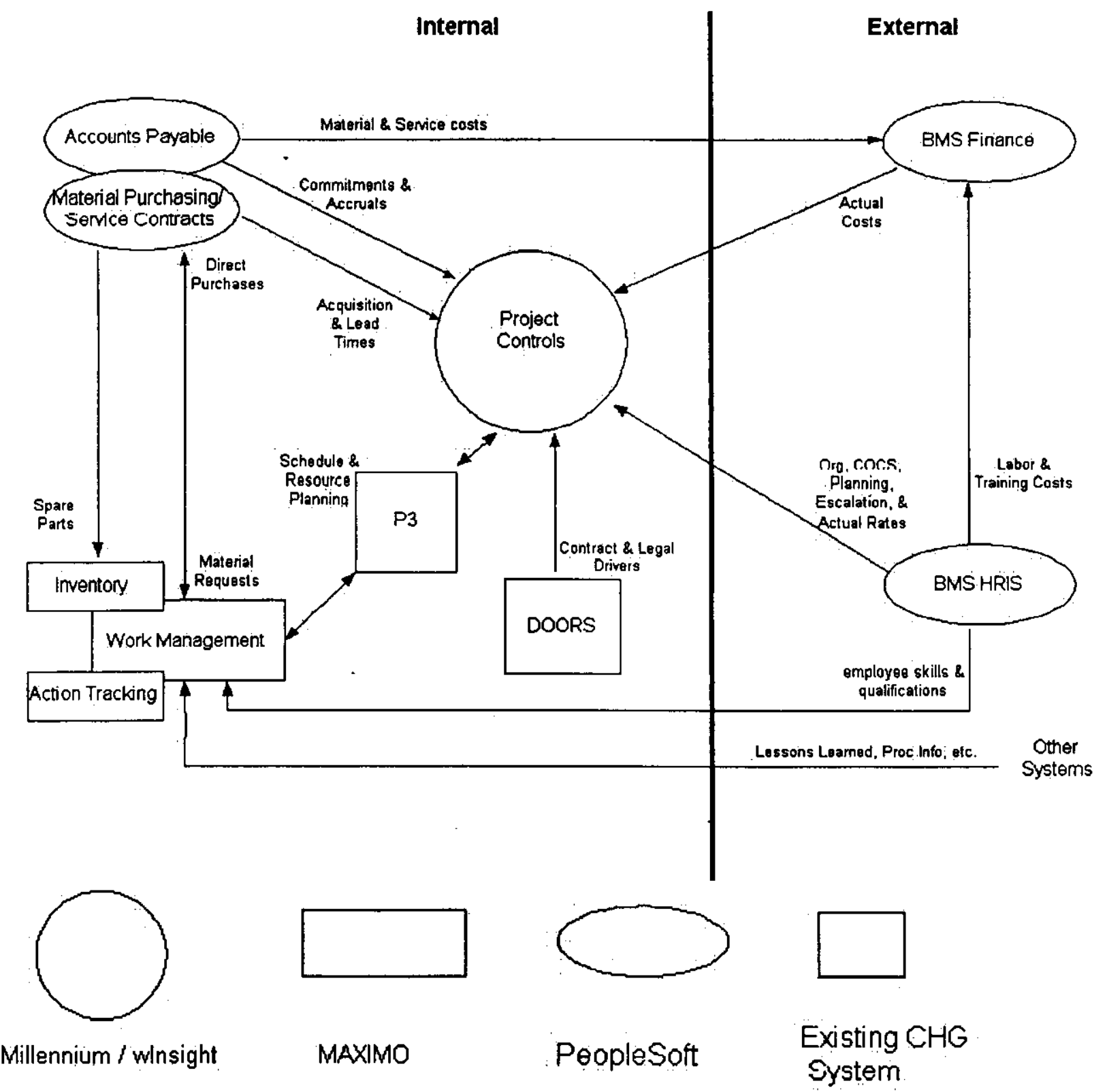




\subsection{INTERFACE DESCRIPTION}

This section provides a high-level description of the interfaces between Project Controls, Work Management, Action Tracking, Purchasing, Inventory and Accounts Payable. Internal interfaces are those interactions within the suite of modules that $\mathrm{CHG}$ would purchase and manage. External interfaces are those interactions with applications that are used on site in a shared environment and managed by $\mathrm{FH}$.

\subsection{Project CONTROLS}

Below are descriptions of the Projects Controls internal and external interfaces.

\subsubsection{Internal}

1) Receive commitment and accrual information from Accounts Payable. Estimates include material and service contract expected costs.

2) Receive schedule and resource planning hours from P3.

3) Receive commitment and accrual data for material, service contracts, leasing equipment, etc.

4) Access to purchasing information, such as lead time information, acquisition plans and statements of work.

\subsubsection{External}

1) Receive actual cost data from BMS Finance. Actual costs include labor, training, material and service costs.

2) Receive organizational data from BMS HRIS, such as Organizational Breakdown Structure, Common Occupational Classification System codes, Planning, Escalation and Actual rates.

3) Access contract and legal drivers for performing work.

\subsection{WORK MANAGEMENT, INVENTORY AND ACTION TRACKING}

Below are descriptions of the Work Management internal and external interfaces.

\subsubsection{Internal}

1) Integrate with Action Tracking, tying actions to work management corrective and preventative maintenance issues.

2) Integrate with Inventory data such as spare parts, stock on hand, preventative maintenance bulk buy materials.

3) Access status of purchases for job scheduling.

4) Enter Material Requests on-line for purchasing of materials and/or service requests.

5) Receive and send scheduling data to and from $P 3$.

\subsubsection{External}

1) Receive employee skills and qualification data from the BMS HRIS training module.

2) Access identified hazards, permit requirements and safety plans from the job hazards system. 
3) Access other external systems to retrieve information such as Unresolved Safety Question, Lessons Learned, procedure information, etc.

\subsection{PURChasing and ACCOUNTS Payable}

Below are descriptions of the Material Management internal and external interfaces.

\subsubsection{Internal}

1) Integration between accounts payable and purchasing for management of vendor payments for services and goods received.

2) Receive material requests from work management resulting from job planning.

3) Send spare part and convenient storage information to the inventory module.

4) Send commitment and accrual data to Project Controls to support forecasting project completion information.

\subsubsection{External}

1) Send detailed material and service rendered project cost information to the shared finance application.

2) Send general ledger transaction data to the shared finance application. 